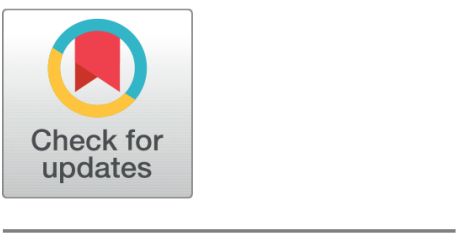

OPEN ACCESS

Received: 05.10.2020

Accepted: 23.03.2021

Published: 17.04.2021

Citation: Borkotoky DK, Borah G (2021) The Impact of Online Education on the University Students of Assam in COVID times. Indian Journal of Science and Technology 14(13): 1028-1035. https ://doi.org/10.17485/IJST/v14i13.1809

* Corresponding author.

Tel: 9863189088

dhirajborkotoky@gmail.com

Funding: None

Competing Interests: None

Copyright: @ 2021 Borkotoky \& Borah. This is an open access article distributed under the terms of the Creative Commons Attribution License, which permits unrestricted use, distribution, and reproduction in any medium, provided the original author and source are credited.

Published By Indian Society for Education and Environment (iSee)

ISSN

Print: 0974-6846

Electronic: 0974-5645

\section{The Impact of Online Education on the University Students of Assam in COVID times}

\author{
Dhiraj Kumar Borkotoky ${ }^{1 *}$, Gitika Borah ${ }^{2}$ \\ 1 Assistant Professor, Department of Political Science, The Assam Royal Global University, \\ Guwahati, Assam, Tel.: 9863189088 \\ 2 Doctoral Scholar, Department of Political Science, Gauhati University, Guwahati, Assam
}

\section{Abstract}

Objectives: To analyse the impact of online education among the university students of Assam. To understand the benefits of online education and the challenges faced by students while accessing online education. Methods: A survey was conducted among the students of two universities of Guwahati (public and private) from India in the month of August 2020. A sample size of 100 students was chosen with the help of random sampling method. A questionnaire consisting of both structured and unstructured questions was prepared to interview the students. Findings: It was found that the online education during COVID-19 times had its own share of pros and cons, many students were of the opinion that classroom teaching cannot be replaced by online teaching and that the new mode of teaching did not have a great impact on their education as they faced many issues with it. Application : The findings from this study can help the teaching community and also the students to understand the basic problems of online education which if corrected can help the teachers to deliver better and the students to understand better.

Keywords: COVID; Halt; Online; Students; Lockdown

\section{Introduction}

The concept of holistic development of an individual is related with the idea of education that one receives. Education plays a very important role in making a person realise the full potential that he or she is capable of. The entire idea of education from the primary level to the highest level had to undergo a major change with the outbreak of the COVID-19 crisis. The whole world came to a standstill with the sudden outbreak of COVID-19. The Novel Corona virus or COVID-19 was identified in $31^{\text {st }}$ of December $2019^{(1)}$ and in March 2020 the World Health Organisation declared it as a pandemic ${ }^{(2)}$. According to WHO, in 235 countries over 3400000 people are infected by this Virus and caused almost 116000 deaths globally ${ }^{(3)}$. The global economy was strangled by the pandemic; the social life of people all over the world got disrupted. World Bank already warned the countries that global economic growth may fall off by $8 \%$ this year ${ }^{(4)}$. International Labour Organization made it clear in the month of March itself that 25 million jobs are in threat due to COVID 19, but soon it was estimated that almost 
2.7 billion workers will get affected by this pandemic ${ }^{(5)}$. Over 40 million people lost their jobs in India itself due to COVID $19^{(6)}$.

With the spread of COVID-19, educational institutions all over the world were closed down. The only way to stop the spread of this deadly virus was to maintain social distancing. India went under complete lockdown from $25^{\text {th }}$ of March ${ }^{\text {(7) }}$. All sorts of educational institutions, offices, shops, transport and communication facilities were closed. The economy was shrinking as the major economic forces like companies, shops and business institutes were forced to be closed. Along with the economic activities, the educational sector took a major blow when all of a sudden the educational institutions all over the world were forced to be closed as it was believed that children were more likely to be affected by the virus. Thus slowly but steadily almost all the educational institutions moved towards online mode of delivering education to the students in different parts of the world. The online classes have a fair share of their perks as well as perils. In a country like India where classroom teaching is followed everywhere, the transformation to online mode of teaching was drastic. The advancements made in online education in such a short period of time are remarkable. A transformation, that was neither easy for teachers nor the students. But this was the only alternative.

The closure of educational institutes all over the world put the future of young students at stake. To cope with this problem online mode of education was followed by all the countries. This was not new for technologically developed European countries. But in India students faced a lot of trouble as they suddenly faced a situation which was unprecedented. Even the teachers had a tough time coping with this transformation. Network connectivity was one of the major problems faced by teachers as well as students. In this study, an attempt has been made to understand the impact of online education on the University students of Assam. There is a plethora of research being done on perks and perils of online mode of education in Covid times. The significance of this paper lie in the fact that prior to this paper that no such study has been done in the context of university students of Assam, so the result of this paper holds significance in the particular area of study. The current study tries to identify the problems faced by the Post-graduate and the undergraduate students (specifically from the humanities stream) while switching to the online mode of education. Thus, the study will help in understanding the problems and concerns of the students faced during online learning and will provide new direction to mitigate these glitches.

\subsection{Objectives}

The major objectives of this study are threefold:

Firstly, it tries to understand how the students have reacted to the online mode of education.

Secondly, it tries to analyse the major issues of online education among the students at the university level in the state of Assam.

Thirdly, the study tries to examine the usefulness of online mode of education which will play an important role in future.

\subsection{Methodology}

This research paper attempts to understand the challenges and opportunities faced by the students regarding online education. With this objective, a survey was conducted among 100 students of two universities in the city of Guwahati, Gauhati University, (Government University) and Royal Global University, (a private university), used as a tool for collection of primary data on the basis of random sampling. The students selected were both from the under-graduate and post-graduate level. To understand the opinion about the faculties involved in online teaching in both the universities, 50 faculty members across various disciplines were also interviewed from both the universities. The major factor used behind the selection of the universities of Assam was based on the fact that there has not been much study about the impact of online education among the university students of Assam. Secondary data was collected from research papers, reports and official websites of World Health Organisation, International Labour Organisation and World Bank etc. The data collected were both qualitatively and quantitatively analysed to understand the present situation of online learning among the university students of Assam.

\section{The Pattern of General Education}

Presently, there are 950 universities in India ${ }^{(8)}$ and these are the backbone of higher education in our country. It's a collection of Central universities, state universities, private universities and deemed to be universities. Indian education system follows the traditional mode of teaching i.e. the classroom teaching. In the traditional mode, the teaching environment consists of teachers and students within the four walls of the classroom. The lecture method is followed where the teachers explain the concepts with the help of blackboard/ whiteboard. The class room teaching is followed all over the country as it provides for a more accessible option. In a developing country like India, where a large section of the society lives below the poverty line, modern teaching 
methods are not accessible to all. Use of computers, internet and projectors for teaching is a dream when some remote areas do not even have electricity facilities. The traditional mode of education provides more scope for teacher-student interaction. There is no connectivity issue in traditional education like online classes, as both the students and the teacher are present at the same class room. In such a teaching environment the teacher is able to give individual attention to all the students. The infrastructures of private universities are much developed in comparison to the government universities in India. With the technological advancements, audio-visual aids like overhead projectors have become an integral part of higher education in India. The use of audio-visual aids makes the process of learning very interesting. But again the use of these tools is subject to the availability of electricity. Sometimes the teachers are not comfortable with the use of technology; they prefer the use of chalk and blackboard over other tools.

In the state of Assam also, traditional mode is followed everywhere as it is a cheaper and easily accessible. Face-to-face interaction in the class room teaching provides a wider scope for interesting deliberations. It helps in developing an emotional bond between the teacher and the students. Unlike online classes there is no disturbance or distractions like network and connectivity issue.

\section{The Halt}

The class room teaching was the most convenient mode of imparting education until the outbreak of COVID-19. With every passing day, the spread of this deadly virus was increasing; the only way to stop this was to break the human chain. As a result complete lock down was declared by the countries that were hit by this virus. In India also complete nationwide lock down was imposed from $25^{\text {th }}$ of March. Initially, the lock down was imposed for a period of 21 days, but gradually the government kept on extending the dates. From $25^{\text {th }}$ of March complete lock down was followed all over the nation; everything was closed except the emergency services like the medical service, police and the media. The economy was hit hard, all the shops, offices private as well as government; educational institutions, transport and communication were close down. The social lives of the people were disrupted. People were literally caged inside their houses; many people even lost their jobs. In essence, COVID-19 created traumas among people.

The educational institutions were closed indefinitely across India. Examinations for class X and XII conducted by the Central Board of Secondary Education were postponed for the COVID situation. In Assam the Board of Secondary Education and Assam Higher Secondary Education Council was able to finish the class X and XII examinations before COVID hit the region. But, gradually the COVID situation deteriorated in the state and soon the quarantine centres ran out of spaces. Subsequently, the educational institutions were turned into quarantine centres across the state. The halt of the whole education system created havoc among the minds of students as well as the teachers. Although the whole education system was shattered, the impact of COVID 19 upon the higher education was severe. So, the idea of online education was introduced. Even it was also not free from uncertainties. The students of the science stream need access to laboratory facilities for their regular classes, but it cannot be provided through the online mode. The research scholars faced even more problems as due to unavailability of laboratory facilities their research work came to a halt. For the social science researchers, the society is the laboratory. Social distancing being the order of the day, social interactions also came to a halt. The researchers from all the streams need to visit different places and different libraries in search of seminal works that may help his or her research. All kinds of educational practices came to a standstill because of this virus. The students are on the verge of losing one precious year of their academic life as semester examinations and entrance examinations are getting delayed.

A transition was made from offline to online mode of teaching. But it raises the question is this the real solution. Is this mode of education accessible for all the students? According to the NSO report in the rural areas of Assam 3.7\% people have computers at their house and $12.1 \%$ of the people have internet facilities. Again in urban areas household with computers is $30.8 \%$ while $46.9 \%$ people have access to internet facilities. In the state of Assam 7.5\% people have computers and 17\% people have access to internet facility ${ }^{(9)}$. The report is based on the data collected from July 2017 to June 2018 and published in November 2019. The situation must have improved in the last two years but it is still not very satisfactory. There is a huge digital divide between the students of rural and urban areas. Even with the introduction of online education, the halt is still there in some parts of the state. Without the proper digital tools and internet facilities the halt will continue ${ }^{(10)}$.

\section{Beginning of Online Education in the COVID situation}

The year 2020 has been one of the most challenging one for almost all the sectors from businesses to education to many more. However, the impact of the COVID and its related effects was more on the education sector all over the world. The entire education sector came to a grinding halt, the schools, colleges and universities all over the world had to be forcefully shut down as the virus started spreading its wings rapidly across continents. In India the first real impact of COVID was when the Prime 
Minister of India had to declare a national lockdown on the $24^{\text {th }}$ March 2020. ${ }^{(11)}$ With the beginning of the lockdown the education scenario also changed, as March is that time of the year when teachers and students begin to hit the peak of the teaching season in India. The entire education world came to a grinding halt in the country, but within weeks of the lockdown the various educational institutes in India began to find out the alternatives to continue with the teaching and engagements with the students. It was here that the faculties in different parts of the country started using the online mode of teaching to continue with the academic engagements with the students. This was a very important step as at times of COVID keeping the students engaged in academic activities was itself a challenge. Teachers across the country at various levels began to shift towards the online mode of education to continue the teaching aspect and keep the students engaged. The major challenges faced during online mode of education include- technological issues, socio-economic factor, digital proficiency, disturbance caused by family members or pets' and absence of supervision etc ${ }^{(12)}$. Use of digital platforms may also lead to privacy and security related issues. The link for the classes or webinars needs to be kept private as making it public will cause stealing of data or hacking etc ${ }^{(13)}$.

In the state of Assam there are 25 universities of repute which are both private and public universities ${ }^{(14)}$. Along with the rest of the country education in Assam also came to a grinding halt, the students at the highest level from various streams such as Arts, Science, Commerce, Engineering, Medical etc. were affected as their on-going semesters were disturbed. It was at this time in the beginning of April 2020 that almost all the major universities began to conduct their classes in a virtual manner. The students in Assam initially faced various problems in adapting themselves to the new method of learning, however after many hiccups the students began to cope with the new method of learning. For the purpose of this particular study a sample survey was conducted among the students of two universities in the city of Guwahati, that is, the Gauhati University and the Royal Global University. A total of 100 students were randomly selected from both the universities across various disciplines. Questionnaires both structured and unstructured were circulated amongst the students to elicit their opinion about the impact of online education on them.

A survey was also conducted among 50 faculty members of both the universities who were involved in online teaching since the beginning of March, a question was asked about the preferred online platform to teach and engage with. $75 \%$ of the faculty members preferred google meet as the most preferred option to teach online. 17\% felt that zoom platform was a better means to teach online whereas a negligible $8 \%$ used webex as a mode to teach online. However, all the faculties had a common concern that is none of the modes of online teaching were compatible with the available network scenario in the North East India.

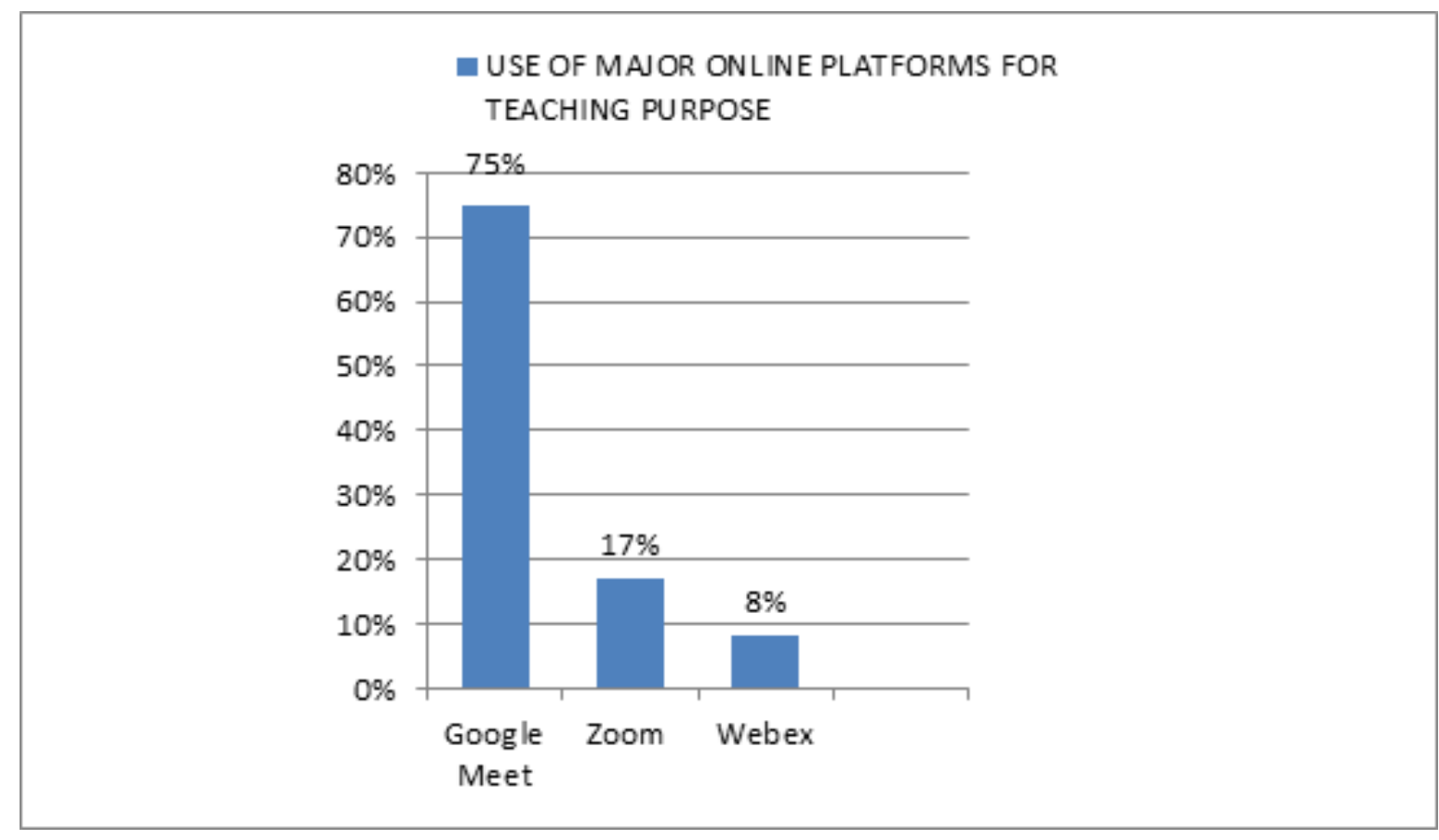

Fig 1. Results showing the percentage of teachers using the various online platforms 


\section{The Impact of Online Education}

The present paper has tried to cover the various issues faced by the students of the University level as they had to switch over to a new mode of teaching and learning since the beginning of March 2020. For the purpose of data collection a range of students were randomly selected from both Gauhati University and Royal Global University across different streams.

\subsection{Result of the Impact on Students using online methods of Learning}

Table 1. Showing the impact of Online Education on the students of Assam

\begin{tabular}{|c|c|c|c|}
\hline Sl. no & Questions asked to students & Variable & $\mathrm{F}$ \\
\hline \multirow[t]{3}{*}{1} & \multirow[t]{3}{*}{ What is the preferred online platform used by you? } & Google Meet & 65 \\
\hline & & Zoom & 22 \\
\hline & & Webex & 13 \\
\hline \multirow[t]{3}{*}{2} & \multirow[t]{3}{*}{ What is you view about online mode of teaching? } & Effective & 43 \\
\hline & & Ineffective & 57 \\
\hline & & Can't comment & 0 \\
\hline \multirow[t]{2}{*}{3} & \multirow[t]{2}{*}{ Can you have proper interaction with teachers during online classes? } & Yes & 30 \\
\hline & & No & 70 \\
\hline \multirow[t]{3}{*}{4} & \multirow[t]{3}{*}{ What was the most important problem with online education? } & Network Issues & 67 \\
\hline & & Electricity Issues & 12 \\
\hline & & Not enough Data & 21 \\
\hline \multirow[t]{2}{*}{5} & \multirow{2}{*}{$\begin{array}{l}\text { Could you have proper access to the study materials during the } \\
\text { pandemic? }\end{array}$} & Yes & 17 \\
\hline & & No & 83 \\
\hline \multirow[t]{3}{*}{6} & \multirow{3}{*}{$\begin{array}{l}\text { Could you understand the theoretical concepts clearly through the } \\
\text { online mode of education? }\end{array}$} & Could understand & 40 \\
\hline & & Difficult to understand & 12 \\
\hline & & Needed few more classes to understand & 48 \\
\hline \multirow[t]{3}{*}{7} & \multirow[t]{3}{*}{ In a single day how many online classes would you prefer? } & 2 & 100 \\
\hline & & 3 & 0 \\
\hline & & 4 & 0 \\
\hline \multirow[t]{2}{*}{8} & \multirow{2}{*}{$\begin{array}{l}\text { Have you been able to adapt yourself to this new mode of teaching } \\
\text { and learning process? }\end{array}$} & Yes & 37 \\
\hline & & No & 63 \\
\hline \multirow[t]{2}{*}{9} & \multirow{2}{*}{$\begin{array}{l}\text { Could you follow a proper routine during the online mode of } \\
\text { education? }\end{array}$} & Yes & 67 \\
\hline & & No & 33 \\
\hline \multirow[t]{3}{*}{10} & \multirow{3}{*}{$\begin{array}{l}\text { Do you believe that online mode of teaching can replace classroom } \\
\text { method of teaching? }\end{array}$} & Yes & 21 \\
\hline & & No & 71 \\
\hline & & Can’t say & 08 \\
\hline
\end{tabular}

\subsection{Analysis and Results}

The results of the structured questionnaire posted to the University students were very clear about the impact that the online mode of education had on the students. $53 \%$ of students were of the opinion that the online mode of education was not as effective as that of the classroom teaching. A huge majority of $71 \%$ of students were of the clear opinion that the online mode of education can never replace the classroom mode of teaching-learning process. A healthy communication between teachers and students is the most vital part of the education process, but the online mode of education has not been able to do that as $83 \%$ of students said that they could not have any proper communication with the teachers during the online classes. There are a lot of technical issues involved with teaching through the digital platforms. Sometimes it takes almost half of the period to resolve these issues. Due to network issues or connectivity problems, one might not be able to hear clearly what the teacher is speaking. Another-network related problem is that people with slower network might get disconnected, so connecting again and again creates distractions for the whole class and the continuity of the discussion is broken. Online classes do lead to fatigue situations as $100 \%$ replied that they prefer to have a maximum of 2 online classes a day. Even after four months of online teaching students at the higher level have not been able to adapt themselves with the online mode of education as $63 \%$ of students found it difficult to adapt themselves with the new mode of learning. 
Along with the structured questionnaire, students were also interviewed about the issues relation to online method of teaching and learning through some unstructured questions. A majority of the students who came from the rural areas of North East India especially the students of various places from Arunachal Pradesh mentioned the fact that online education was not a feasible option for them as most of the time they were without electricity or mobile networks. An interesting observation was made by almost all students that during the lockdown phase they did not have the proper environment at home to concentrate in their studies through the online methods as there were other issues to be dealt with in the family. The fact of the matter is the environment that one gets in the classroom cannot be provided in any other place, as the classroom learning is the best way to engage students to maximize their potential. The students were also of the opinion that it was not possible to concentrate in their studies due to the constant fear of the virus as psychologically the issue of being affected by the virus does not allow the students to have a stable mind to continue with their studies normally. Another cause of concern for the students was the overlapping of classes. In offline mode of education, every educational institute follows a definite timetable that clearly defines the teacher allocated for a particular period. But as online mode of teaching is flexible and there is no rigorous time table, classes of different teachers gets overlapped. The issue of flexibility of classes is helpful as the teachers and the students can decide a time for the class which is convenient for all. But again for a class of 50 students deciding a time that is suitable for each student is problematic.

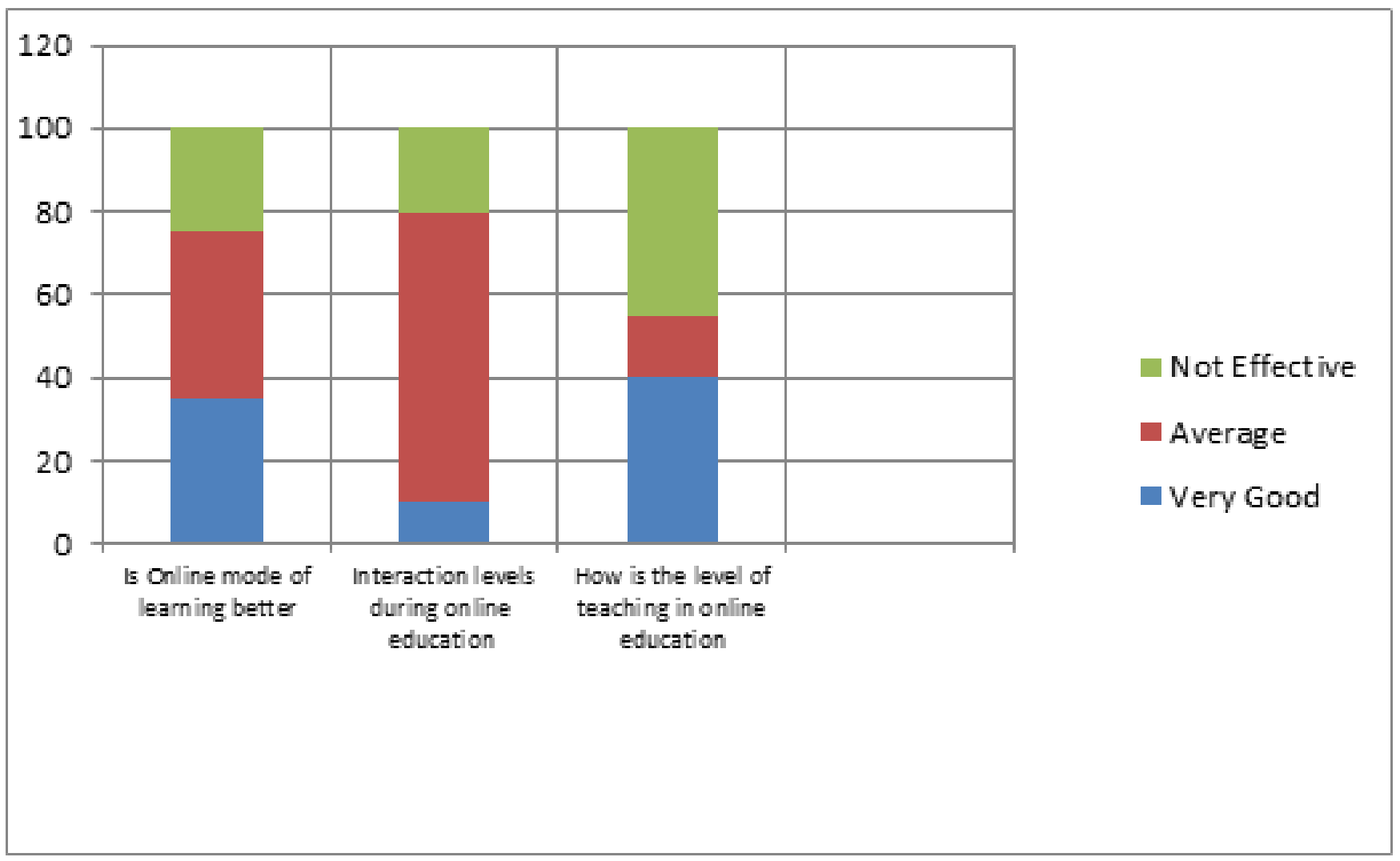

Fig 2. Showing the general observations of the students towards online education.

\section{Results and Discussion}

The main focus of the present study was the impact of the online education on the students at the university level in the city of Guwahati. After almost four months of online teaching and learning process it is clear that the students have not been able to fully cope up with the online mode of teaching. As it is evident from the views of the students that, online teaching, is not as effective as the classroom based way of teaching. Amidst the pandemic it is very important that the students are motivated to be in constant touch with their teachers and their syllabuses, but completely shifting to the new mode of teaching has created other problems for the students which are of psychological in nature. At the university level a student needs constant guidance 
and motivation which the online mode of education has not been able to deliver. At the masters level it is very important that a student has very clear idea about his or her subject and the online mode of education is not as effective in helping a student getting clear idea about certain topics. The students were of the clear opinion that they were having a tough time to continue with their regular studies in the absence of the classroom based education. In such a situation most of the teachers and students had to depend on whatsapp to continue with their regular learning process. ${ }^{(15)}$

A category of students were of the opinion that the online mode of learning did not really help them to understand theoretical concepts. This is something very important as theoretical concepts are not easy to understand through an online class of 40 to 50 minutes. Theoretical concepts both from Science and Arts background cannot be easily taught through the online mode of education where there are no direct interactions between a teacher and the students. Education today is all about the proper use of the available resources for the students to study, but during the pandemic it was observed that the students were restricted in having access to proper study materials as a majority of the students were of the opinion that they could not get access to the study materials as suggested to them by the teachers. Online resources are important but having access to the study materials in the physical library plays a crucial role in the development of the knowledge base of a student. The impact of COVID 19 on the students has been universal in nature as students ranging from various countries have expressed the views that access to online education is the biggest challenge in the present environment.

The COVID-19 crisis had brought forward a very pertinent issue in front of the administrators, teachers and also students about the importance of technology in terms of network connectivity. Internet connectivity remains to be a major issue in India and especially in the North Eastern region. India needs a major revolution in terms of providing internet connectivity. According to Kumar with regard to the communication networks, the good news is that the National Broadband Mission is already progressing fast to provide broadband access to every village in India by 2022 . This mission is expected to enable all rural and remote areas of India to have equitable and universal access to broadband services. In the near future, 30 lakh $\mathrm{km}$ of optical fiber cable will be laid and the towers are expected to increase from the existing 5.65 lakh to 10 lakh. The speeds are expected to reach 50 mbps. ${ }^{(16)}$ COVID-19 has proved a point that education in future will have a greater online dependence, thus the State needs to ensure that every student has access to open internet so that he or she is not deprived of education because of lack of resources.

Olasile Babatunde Adedoyin and Emrah Soykan in their paper "Covid-19 pandemic and online learning: the challenges and Opportunities" identified the challenges and opportunities created by online learning. The global challenges according to them are- Technology;Socio-economic factor; Human and pets' intrusions, Digital competence; Assessment and supervision; Heavy workload; Compatibility. The present study suggests that in Assam also the students faced similar kind of challenges like technological issues, financial issues and digital competence to name a few. In a survey conducted on the Agricultural students from India it was found that though some students expressed satisfaction over online classes; most of them preferred traditional classes over online classes. Technological hindrances and lack of technological competence were pointed out to be major issues in online teaching. ${ }^{(17)}$

Dickson Adomin his study "Cultural and Educational Implications of the COVID-19 Global Pandemic in Ghana" analysed the implications of Covid-19 pandemic on the education sector. According to Dickson Adom, adapting to online mode of education was not easy for Ghana due to "lack of technical-know-how", "the high cost of the internet infrastructure". (18)

\section{Conclusion}

The online education, which has become the order of the day, has had its own share of negatives as well as positives. After almost four months of online education it was found that the students have not been able to adapt themselves to the online mode of education. The COVID 19 situation has created problems all over the world at various levels. Education was no exception for its fair share of problems created by the pandemic. The online mode of education is not the solution to the problems the pandemic has created as in far off places such as the remote corners of North East India there are multiple issues with the online mode of education. Online education through various platforms in a virtual manner might help in the progress of the syllabus, but not the overall development of a student as they miss a very important part of life that is interactions with their peers and the teachers in the classroom and beyond. Without the proper infrastructure online mode of education cannot be the panacea to the problems created by COVID across the nation. However, in spite of all its shortcomings, it needs to be accepted that online mode of education has actually allowed education to continue in India and the rest of the world, thus the need of the hour is to inculcate a habit among the students from a very early level to develop interests towards online mode of education and keep themselves abreast with the technological advancements of online education and its challenges in the future. There is no doubt that education in future will rely more on technological innovations and thus it becomes the prerogative of the State to infuse the various concepts of technology among the students from a very early stage in life. 


\section{Acknowledgement}

Authors thank the concerned teachers and students of both Gauhati University and Royal Global University for their support in writing this research article. The inputs of our fellow faculty colleagues is also highly appreciated.

\section{References}

1) Archived: WHO Timeline - COVID-19. . Available from: https://www.who.int/news-room/detail/27-04-2020-who-timeline---covid- 19.

2) WHO Director-General's opening remarks at the media briefing on COVID. 2020. Available from: https://www.who.int/dg/speeches/detail/who- directorgeneral-s-opening-remarks-at-the-media-briefing-on-covid- .

3) Coronavirus disease (COVID-19) pandemic. . Available from: https://www.who.int/emergencies/diseases/novel-coronavirus-2019.

4) The Global Economic Outlook During the COVID-19 Pandemic: A Changed World. . Available from: https://www.worldbank.org/en/news/feature/2020/ 06/08/the-global-economic-outlook-during-the-covid-19-pandemic-a-changed-world\#: :text=Businesses\%20might $\% 20$ find $\% 20 \mathrm{it} \% 20 \mathrm{hard}$.

5) COVID-19: impact could cause equivalent of 195 million job losses, says ILO chief. . Available from: https://news.un.org/en/story/2020/04/1061322.

6) Opinion: Impact of covid-19 on the Indian Economy. . Available from: https:/government.economictimes.indiatimes.com/news/economy/opinionimpact-of-covid-19-on-the-indian-economy/75021731.

7) PM Modi announces 21-day lockdown as COVID-19 toll touches 12. 2020. Available from: https://www.thehindu.com/news/national/pm-announces21-day-lockdown-as-covid-19-toll-touches-10/article31156691.ece.

8) UGC. . Available from: https://www.ugc.ac.in/oldpdf/Consolidated\%20list\%20of\%20All\%20Universities.pdf.

9) NSS 75th Round. . Available from: http://www.mospi.gov.in/sites/default/files/NSS75252E/KI_Education_75th_Final.pdf.

10) Dhawan S. Online Learning: A Panacea in the Time of COVID-19 Crisis. Journal of Educational Technology Systems. 2020;49(1):5-22. Available from: https://doi.org/10.1177/0047239520934018.

11) Twenty-one day Nationwide lockdown announced', in The Assam Tribune. Available from: http://www.assamtribune.com/scripts/at.asp?id=mar2520/ Pagel.

12) Adedoyin OB, Soykan E. Covid-19 pandemic and online learning: the challenges and opportunities. Interactive Learning Environments. 2020 ;p. 1-14. Available from: https://doi.org/10.1080/10494820.2020.1813180.

13) Saxena K. Coronavirus accelerates pace of digital education in India. EDII Institutional Repository. 2020. Available from: http://library.ediindia.ac.in: 8181/xmlui/bitstream/handle/123456789/10145/EdTechReview\%20by\%20Dr.\%20Kavita\%20saxena\%2017Apr2020.pdf?sequence=1\&isAllowed=y.

14) Profiles of Universities and Colleges. . Available from: https://highereducation.assam.gov.in/portlets/profiles-of-universities-and-colleges.

15) Mishra L, Gupta T, Shree A. Online Teaching-Learning in Higher Education during Lockdown Period of COVID-19 Pandemic. International Journal of Educational Research Open. 2020;1:1-8. Available from: https://doi.org/10.1016/j.ijedro.2020.100012.

16) Kumar MJ. COVID-19: How Institutions, Teachers and Students in India have geared up for Online Education? IETE Technical Review. 2020;37(3):221222. Available from: https://dx.doi.org/10.1080/02564602.2020.1774977.

17) Muthuprasad T, Aiswarya S, Aditya KS, Jha GK. Students' Perception and Preference for Online Education in India During COVID -19 Pandemic. Social Sciences \& Humanities Open. 2020. Available from: https://dx.doi.org/10.2139/ssrn.3596056.

18) Adom D. Cultural and Educational Implications of the COVID-19 Global Pandemic in Ghana. International and Multidisciplinary Journal of Social Sciences. 2020;9(3):202-229. Available from: http://doi.org/10.17583/rimcis.2020.5416. 